\title{
Changes in IT Governance for Business Transformation in Banking Industry: Case of PT $\mathrm{XYZ}$ in Indonesia
}

\author{
Aristides Fariz, Ruth Magdalena, Theresia Nathania A. P., Muhamad Yasil F., M. Rifki Shihab
}

\begin{abstract}
Changes in IT governance is urgently needed to support the business transformation. PT XYZ is a bank that transformed its business model to compete optimally in today's digital era. The reasons are to modernize legacy systems and existing work units, develop more customer-centric products, and expand banking service coverage. This research's objectives were to look at elements of IT governance by De Haes \& Grembergen which are structures, processes, and relational mechanisms. The analysis was carried out by looking at the condition of the bank before and after the transformation that happened because of changes in the governance of IT decision making that will be seen using theory from Weill \& Ross. Data were collected from annual and internal reports, also interviews with parties related to IT governance at PT XYZ. The results of this research showed that transformation happened in all elements of IT governance. Changes in organizational structure and alignment processes between business and IT, as well as product development methods such as the application of bi-modal governance, which uses both waterfall and agile, occurred after the transformation. Recommendations are given to PT XYZ to restructure the organization and schedule regular meetings to affiliate IT project development.
\end{abstract}

Keywords : Banking Industry, Business Transformation, IT Governance

\section{INTRODUCTION}

Today, IT governance has become a common practice in almost every company. In its application, it is not enough to develop a high-level IT Governance model. Further studies are needed so that all aspects can work well and sustainably [1].

$\mathrm{XYZ}$ is a bank that is changing its business model to face challenges in the digital era now. Based on an interview with Group Head of Strategic Management, the reasons for XYZ's transformation include the need to modernize existing systems and work units, so it will be more flexible in

Revised Manuscript Received on January 10, 2020.

* Correspondence Author

Aristides Fariz*, Faculty of Computer Science, University of Indonesia, Jakarta, Indonesia. Email: aristides.fariz@ui.ac.id

Theresia Nathania A. P., Faculty of Computer Science, University of Indonesia, Jakarta, Indonesia. Email theresia.nathania81@ui.ac.id

Ruth Magdalena, Faculty of Computer Science, University of Indonesia, Jakarta, Indonesia. Email: ruth.magdalena81@ui.ac.id

Muhamad Yasil F., Faculty of Computer Science, University of Indonesia, Jakarta, Indonesia. Email: muhamad.yasi181@ui.ac.id

M. Rifki Shihab, Faculty of Computer Science, University of Indonesia, Jakarta, Indonesia. Email: shihab@ui.ac.id innovating and supporting the business more optimally. The product developed in the future will be more customer-centric with better product delivery, leading to customer engagement and more productive in providing services, as well as digitizing the process for faster and better user experience. This transformation also aims to create the ability to provide services with a broader range of areas.

This research will discuss the application of IT governance elements, by analyzing the transformation of IT governance at XYZ. Refers to the study from De Haes and Grembergen [1] on IT governance in the Belgian financial institution, this study will analyze XYZ's processes, structures, and relational mechanisms before and after the business transformation of the organization. Just like Manoj Kulkarni's research [2], this study also conducts how XYZ's IT governance structure in regards with the business transformation of the company and it was followed by the presence of fintech as a disruptive phenomenon on the banking industry. Thus, all components related to the transformation of IT governance from XYZ will be presented in order to enrich the current literature. Moreover, the last part of this paper is the conclusion of this research, with some recommendations for XYZ's next IT governance.

\section{LITERATURE REVIEW}

\section{A. IT Governance}

The definition of IT governance is the way organization manages and controls the relationship between business and IT by utilizing elements of IT governance framework, so that IT investment can create value for organization's business [3].

Three elements of IT governance as stated by De Haes and Grembergen [3][4] are: 1) IT governance structures that define all units and roles inside the organization that are responsible in decision making and control activities related to IT;2) IT governance processes that formalized the procedures of IT decision making and controlling to make sure business-IT alignment, includes all frameworks that are used as procedures on the IT governance; and 3) Relational mechanisms that manage the collaborative relationship between executives, business management, and IT management to make sure the sustainability of the IT governance.

IT governance contains five domains [5]: 1) IT principles that organize IT

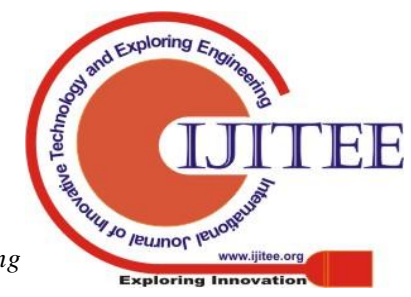


function that will be used for business, 2) IT architecture that manages data, application, and infrastructure in an organization 3)

IT infrastructure to measure and control IT services for company's capabilities 4) business application needs to specify the business requirements and methods for each IT application initiation, and 5) IT prioritization and investment to make decisions and allocation of funds for IT procurement.

Each decision can be made either from the corporate, business unit or functional level or combination from those three. Weill \& Ross [5] defines six archetype approaches on IT decision making: 1) business monarchy - individual or group of business executive, can also involve CIO, 2) IT monarchy - individual or group from IT executive, 3) feudal business unit or process leaders, 4) federal - collaboration between business unit representatives and IT department 5) IT duopoly - IT executives and business leaders, and 6) anarchy - individual or group from IT department or business unit.

\section{B. IT Governance in Banking Industry}

There are few studies specifically discuss IT governance in banking. Mpho Leketi's research [6] says there is no reference model regarding IT governance in South African banking. Many South African banks establish in-house IT governance frameworks. Croatia is one of the literature which the corporate IT governance model is built based on the rules of the Basel Committee for Banking Supervision (II). The model focuses on IT governance to reduce IT risk. On the other hand, India adopted a different IT governance model approach [2]. It can be said that many banks in the world have different approaches in implementing IT governance models and processes because they have different internal business processes [6]. IT governance is also used in the academic world [7] and other industries, as in Boris Otto's research on beverage manufacturers and distributors [8]. Boris [8] examines how organizational transformation can determine IT governance which is relevant to this research because XYZ has adjusted IT governance with the business transformation. Some previous researches, including researches with case studies in banking, use COBIT as an IT governance framework and consider COBIT as the most effective and reliable framework [1][6][8].

\section{THEORETICAL FRAMEWORK}

As mentioned before, XYZ needs to transformation by modernize legacy systems and existing work units, develop more customer-centric products, and expand banking service coverage. These needs drove XYZ to change its IT governance to make an efficient and effective process of making IT-related decisions.

XYZ's changes on the IT decisions governance will be analyzed using a framework from Weill \& Ross [5]. The elements of IT governance before and after transformation, which are structures, processes, relational mechanisms, will be analyzed using the framework from De Haes \& Grembergen [2][3].
This section describes the theoretical framework that is used in this paper. The theoretical framework can be seen in Fig. 1.

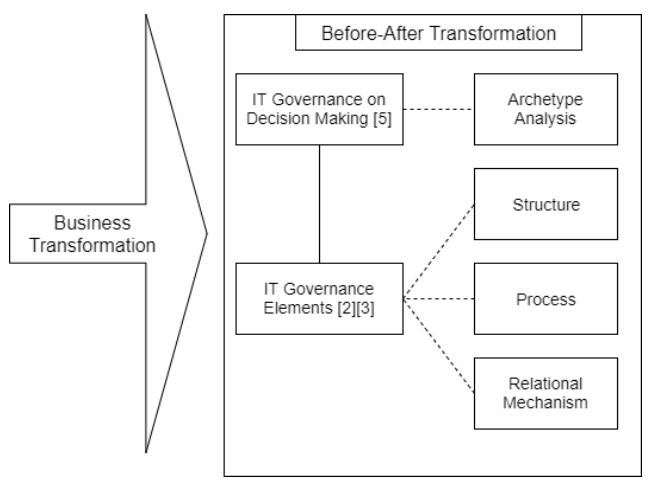

Fig. 1. Theoretical Framework

XYZ's changes on the IT decisions governance will be analyzed using a framework from Weill \& Ross [5]. The elements of IT governance before and after transformation, which are structures, processes, relational mechanisms, will be analyzed using the framework from De Haes \& Grembergen [3].

\section{METHODOLOGY}

The purpose of this research is to find out what XYZ has done in transforming IT Governance to support its business transformation. Using a framework from De Haes \& Grembergen [1], this research will see the transformation from the processes, structures, and relational mechanisms of the IT governance itself. Besides, this study will provide recommendations to $\mathrm{XYZ}$ in dealing with digital disruption to provide business benefits for XYZ.

This research methodology uses a qualitative approach. Semi-structured interview technique is used to gather information from middle-level management. The interviews were carried out to Group Head of IT Development, Group Head of Strategic Management, and IT Business Relations (IBR). Internal organization document is analyzed to obtain secondary data. All data that has been obtained is processed using coding techniques. The codified data is mapped and analyzed. The results of the analysis will then conclude what benefits XYZ will get in implementing IT governance changes for its business. The flow of research conducted in this study is illustrated in Fig. 2. 


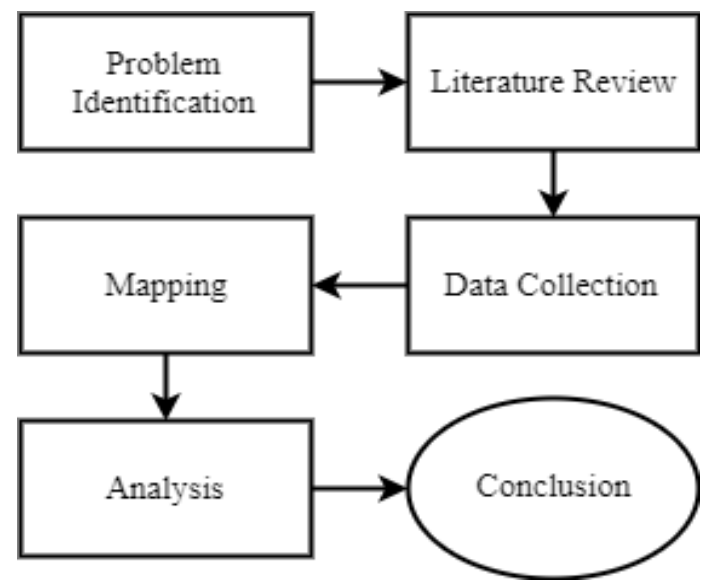

Fig. 2. Research Flow

\section{BEFORE TRANSFORMATION}

\section{A. IT Governance Archetype}

In determining IT principles, the design and proposal were carried out by the IT Strategic Management department. The decision was determined by the Director of Operational. For IT Infrastructure and Architecture, design and capacity planning were analyzed by each part of the development team and approved by the Head of Technology and Operating System Division. Every business application initiated by each business division to be discussed with the Corporate Strategy division and the Management Accounting and Finance division. This agenda was carried out at the end of each year to discuss prioritization, targets and project budgets for next year. For investment in IT, project proposals that have been designed by business units will be discussed in IT alignment activities with the IT department to prioritize future project development. The decision was made by the Head of the IT division.

Table- I: IT Governance Archetype of XYZ Before Transformation

\begin{tabular}{|c|c|c|c|c|c|c|c|c|c|c|}
\hline \multirow[b]{2}{*}{ Input(I)/Decision(D) } & \multicolumn{2}{|c|}{ IT Principles } & \multicolumn{2}{|c|}{ IT Infrastructure } & \multicolumn{2}{|c|}{ IT Architecture } & \multicolumn{2}{|c|}{$\begin{array}{c}\text { Business } \\
\text { Application }\end{array}$} & \multicolumn{2}{|c|}{$\begin{array}{c}\text { IT Prioritization } \\
\text { Investment }\end{array}$} \\
\hline & $I$ & $D$ & $I$ & $D$ & $I$ & $D$ & $I$ & $D$ & $I$ & $D$ \\
\hline Business Monarchy & & & & & & & $\mathrm{X}$ & & & \\
\hline IT Monarchy & $X$ & & $\mathrm{X}$ & $\mathrm{X}$ & $\mathrm{X}$ & $\mathrm{X}$ & & & & \\
\hline Feudal & & $\mathrm{X}$ & & & & & & & $X$ & \\
\hline Federal & & & & & & & & $\mathrm{X}$ & & $\mathrm{X}$ \\
\hline Duopoly & & & & & & & & & & \\
\hline Anarchy & & & & & & & & & & \\
\hline
\end{tabular}

\section{B. IT Governance Structure}

Division of Technology \& Information System is led by Head of Division and put under Directorate of Operational. The directorate is led by Director that will directly report to President Director, hereafter will report to the General Meeting of Shareholders and Board of Commissioners. IT governance structure in XYZ before business transformation can be seen in Fig. 3 .

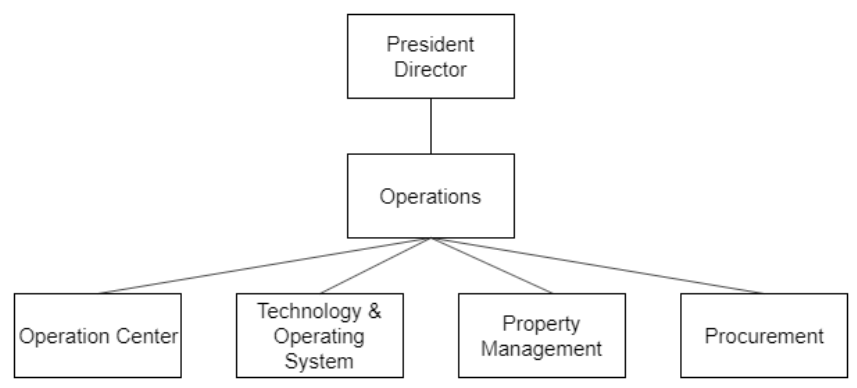

Fig. 3. IT Governance Structure before Business Transformation [9] (has been reprocessed)

\section{IT Governance Process}

Before the transformation, XYZ already has some internal policies that are used as the guidance and control for the IT governance process. The IT unit develops policies, standards and procedures for the use of IT in IT Strategic Plan (ITSP) document. This document is used to help business and IT executives to make the decision for IT domains because IT is expected to become a strategic enabler and partner for XYZ's business development. The ITSP consists of 4 (four) steps to implement IT project in XYZ [10]: 1) Enterprise Architecture: create executive summary of the project initiation; 2) Assessment Phase: business \& IT will assest the initiation together; 3) Design Phase: design the enterprise architecture for implementing the project; and 4) Transition Plan Phase: build application and infrastructure.

\section{IT Governance Relational Mechanism}

IT alignment activity is held annually for prioritizing project planning based on the blue book that has been prepared. This activity involves related business section and the IT department, includes Head of Division and Head of Department. Each project will be initiated by making Business Requirement Specification (BRS) document by the relevant business department.

The project will be started according to the agreed timeline. Each BRS will later be accepted by the IBR department who will then compile a Control Analysis Document so that the project to be developed will have the function and flow as expected by the user. IBR are responsible for all discussion related to the project, starting from the project's timeline to the depth of the application that will be designed since

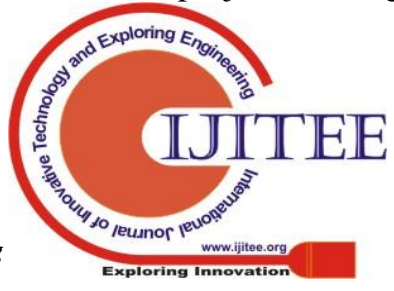


kick-off until finalization between the business and IT departments. Then, related IT System Analyst will accept the disposition of the project and develop it with the development team according to the Software Development Life Cycle (SDLC) method that was adopted using waterfall method.

\section{AFTER TRANSFORMATION}

Technology advances drive changes on customers' behaviour and also make new competitors, which are fintech [3] and maybe digital giants [11], for XYZ. This condition drives XYZ to do business transformation by using IT as the backbone for its service. This condition drives XYZ to do business transformation by using IT as the backbone for its service [11].

Business transformation has brought the company to $5 \mathrm{C}$ as a priority strategy namely Current Account Saving Account (CASA), Customer Focus, Credit Excellence, Capabilities, Culture, which focuses on micro, small, and medium enterprises (MSME), consumer, corporate, and subsidiary companies.

IT is considered as an essential part of implementing corporate strategy. Therefore, XYZ introduced a new directorate, i.e. Directorate of IT \& Operations.

XYZ's main IT procedures come through the 2018-2022 ITSP, which creates business-IT alignment and supports the vision and mission of IT by carrying out IT governance.
XYZ's IT governance is run under government regulations and directors' decisions that include IT risk management and management policies to guide and control all IT work units. XYZ uses leading technology standards as corporate IT best practices such as TOGAF for IT architecture, COBIT for IT governance, and ITIL for IT governance implementation.

\section{A. IT Governance Archetype}

After the implementation of business transformation, there is a change in the flow of policy determination in the company. For IT Principles, the initiation is still being carried out by the IT strategic management department, but now decisions are made by the Director of IT \& Operations. Department of IT Architecture \& Planning now proposes initiatives for IT Infrastructure and Architecture, then decisions will be made by Head of Development for the application level or by Director of IT \& Operations for more significant scope. In determining IT prioritization, besides the initiations that come from the business unit, the IT department can now propose priority for projects originating from regulators or audit teams. Decisions related to project prioritization will be made together between business and IT executives. Meanwhile, the process of developing business applications is almost the same as before the transformation.

Table- II: IT Governance Archetype of XYZ After Transformation

\begin{tabular}{|c|c|c|c|c|c|c|c|c|c|c|}
\hline & \multicolumn{2}{|c|}{ IT Principles } & \multicolumn{2}{c|}{ IT Infrastructure } & \multicolumn{2}{c|}{ IT Architecture } & \multicolumn{2}{c|}{$\begin{array}{c}\text { Business } \\
\text { Application }\end{array}$} & $\begin{array}{c}\text { IT Prioritization } \\
\text { Investment }\end{array}$ \\
\hline Input(I)/Decision(D) & I & D & I & D & I & D & I & D & I & D \\
\hline Business Monarchy & & & & & & & $\mathrm{X}$ & & & \\
\hline IT Monarchy & $\mathrm{X}$ & $\mathrm{X}$ & $\mathrm{X}$ & $\mathrm{X}$ & $\mathrm{X}$ & $\mathrm{X}$ & & & & \\
\hline Feudal & & & & & & & & & & \\
\hline Federal & & & & & & & & $\mathrm{X}$ & & \\
\hline Duopoly & & & & & & & & & $\mathrm{X}$ & $\mathrm{X}$ \\
\hline Anarchy & & & & & & & & & & \\
\hline
\end{tabular}

\section{B. IT Governance Structure}

The company's organizational structure can show how effective IT governance is through the placement of IT directorate in the company's IT decision making[1]. Following the business transformation of XYZ, the biggest difference in the IT governance structure can be seen as IT division is introduced as a new directorate. This new structure makes IT as an essential part of the decision making for XYZ.

Directorate of IT \& Operations is led by Director, who is also called CIO, and supervise six divisions. Each division is led by Head of Division. CIO is responsible to report directly to Vice President Director, who is part of the Board of Directors. Then, the Board of Directors will report to the General Meeting of Shareholders and the Board of Commissioners.

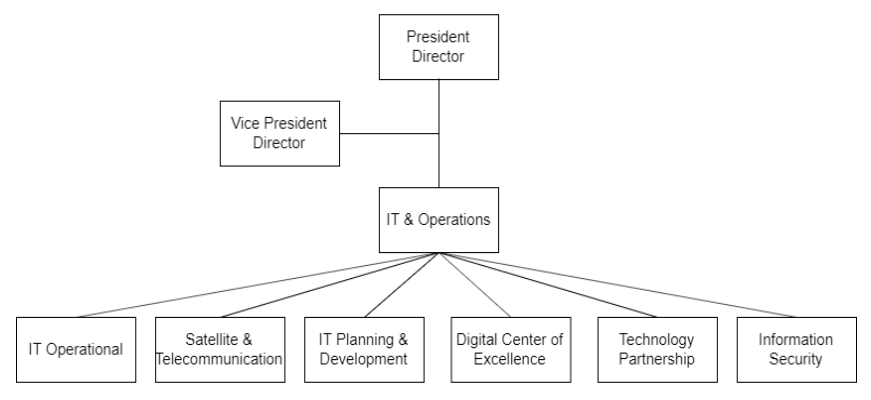

Fig. 4. IT Governance Structure after Business Transformation [12] (has been reprocessed)

Specifically, Directorate of IT \& Operations has an IT Steering Committee in carrying out IT governance. This committee is responsible for providing recommendations to the Board of Directors, the Board of Commissioners and General Meeting of Shareholders regarding IT

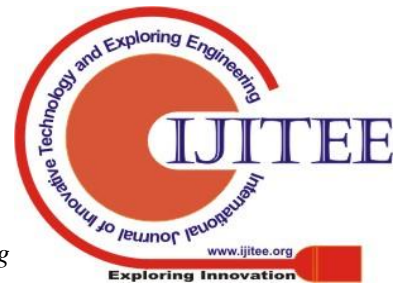


planning, governance, development and operations. The IT Steering Committee is also tasked with controlling, monitoring, evaluating IT development and implementation at XYZ following corporate strategy. In XYZ, members of IT Steering Committee are $\mathrm{CIO}$ and related Directors, program owner, owner of business initiatives, system integrator, enterprise architect, and reporting team.

\section{IT Governance Process}

XYZ's IT governance process is carried out using COBIT and ITIL standard to align business and IT strategies to achieve the desired performance [6]. COBIT framework is adopted and implemented in XYZ's IT governance [4][6]. Every process in the framework is carried out by ITIL for XYZ IT services management. Thus, the presence of COBIT and ITIL in XYZ IT governance are two complementary frameworks and the most implemented models in institutions, including banking [3][7].

Business initiation is carried out through various IT project implementations [3]. Therefore, IT project priorities are vital, and XYZ's IT governance includes monitoring and reviewing IT projects. Every IT-related work program must be included in the Bank's Business Plan (RBB) with precise requirements and specifications. The IT work program is certainly aligned with strategic initiatives and outlined in XYZ's corporate plan. Each strategic initiative from corporate planning is mapped to each directorate according to strategic needs.

IT division regularly reviews the project portfolio and do monthly project plans.

Then, Division of IT Planning \& Development assigns IBR to each business unit as an IT project coordinator who is aware of the business strategy initiatives. Therefore, IBR will work to ensure that all IT projects align with the directorate's strategic initiatives through an alignment meeting. IBR also tasked to monitor each IT project and as a mediator of communication between the business and the IT division.

Fig. 5 shows the IT governance process in which each process has several parties responsible for its implementation and monitoring. Corporate strategy comes from the vision and mission of XYZ, which is under the authority of the Board of Directors, Directorate, General Meeting of Shareholders (RUPS), s and Board of Commissioners. All directorates, including IT and businesses, which are represented Head of Division, discuss the requirements together with IBR and Head of Application Development. The discussion resulted in the number of IT projects submitted to the IT Steering Committee who will determine the project priority list.

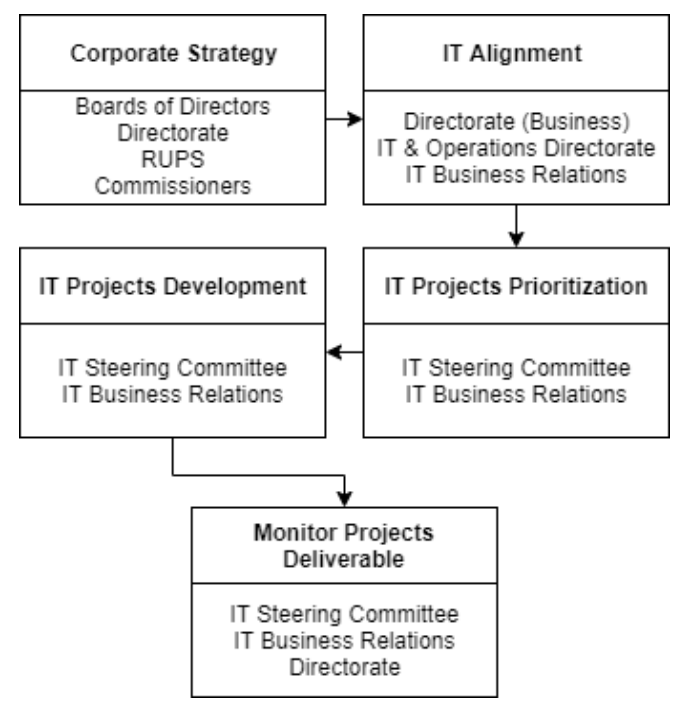

Fig. 5. The design of determining priorities for XYZ IT project implementation

IT project priorities are often determined directly by the Directorate of IT \& Operations and IBR. Projects are built based on priority urgency, the need for current problems, government regulations, and few that are aligned with the company's initiative strategy. Current IT projects are initiated through communication between Directorate of IT \& Operations and other business Directorates to discuss the requirements without involving other related parties.

For the development, IT projects are divided into waterfall and agile methodology based on the requirements. Project for core banking system will use waterfall and project related to enhancement current banking feature will use agile, this is called as bi-modal governance in XYZ. In the development process, there is some delay that happens because of the collaboration issue between the development team in Division of IT Planning \& Development with Quality Assurance \& IT operational team in Division of IT Operations. The problem occurs because some regulations related to testing and deployment hinder the delivery of product delivery. Similarly, when it needs to do monitoring and troubleshooting that can not be done quickly because regulations hamper it.

\section{IT Governance Relational Mechanism}

In 2018, the IT Steering Committee only held two meetings with the decision reached by the quorum. Thus, in practice the priorities and monitoring of IT development are often taken over by some members of IT Steering Committee itself, such as the CIO and Head of IT Division. Formal meeting between IT and business divisions are not scheduled regularly. Business and IT discuss about applications that urgently needed to be developed in daily meeting. The development of the applications did not go through the proper approval process of IT Steering Committee and IBR. As a result, there has been some bottleneck in starting the projects because some of IT projects prioritization does not come through IT Project Prioritization Design.

To support

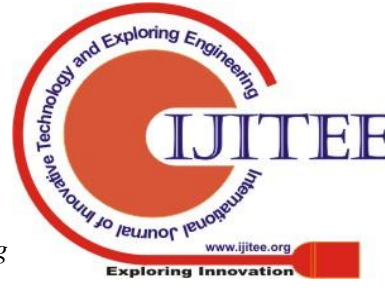


development of more agile projects and faster delivery processes, XYZ uses third-party tools, such as Jira and Bitbucket, for more detailed project needs analysis and monitoring. The documentation and reporting functions also use Confluence, which can also be monitored by the relevant team supervisors.

\section{CONCLUSION}

This research contributes to displaying differences in IT governance before and after transformation so that they can see the difference between the two and the benefits they generate. The transformation of XYZ's digital business has a direct impact on the transformation of IT governance. The use of frameworks such as TOGAF, COBIT, ITIL, help the IT governance process be more directed. XYZ also introduced bi-modal governance for the development process, which divides projects to waterfall or agile for the software development methodology. The benefits experienced by XYZ in implementing a good IT governance are the lack of overlap in one part that impacts on the development of the same application, better workload sharing between IT divisions, and the performance of IT applications is better because IT risk is minimized.

We recommend $\mathrm{XYZ}$ to restructure its organizational structure to have a new digital transformation unit as we also refer to the critical success factors on IT governance [13] because in current IT division structure, there is some delays that happens because of the collaboration issue. This is the background why XYZ needs to change its IT organization structure. All parties related to IT development and support will be put together under one division. Proposed IT organization structure can be seen on Fig. 6.

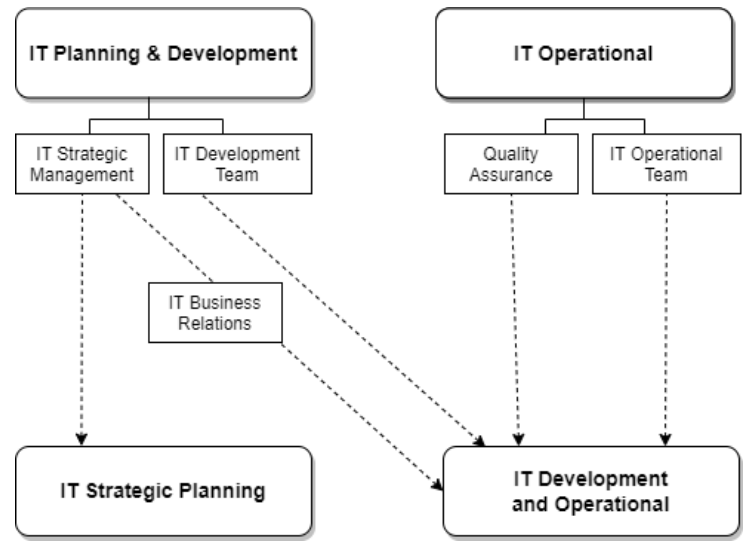

Fig. 6. Change on IT Division

For the prioritization issue, we recommend $\mathrm{XYZ}$ to regular schedule meeting between all so that there will be no longer misleading IT projects development that is not aligned with XYZ business objectives. This also could open communication and participation among divisions between IT and business [14]. The organizational structure that we have recommended will make the IBR function closer to the development team so that communication and project control will be more organized.

\section{REFERENCES}

1. S. De Haes and W. Van Grembergen, "IT Governance Structures, Processes and Relational Mechanisms: Achieving IT/Business Alignment in a Major Belgian Financial Group," Proc. Annu. Hawaii Int. Conf. Syst. Sci., no. May, p. 237, 2005.

2. M. Kulkarni, "IT Governance in Global Banks: Emerging Models.," Vinimaya, vol. 39, no. 1, pp. 11-21, 2018.

3. W. Van Grembergen and S. De Haes, Enterprise Governance of Information Technology. New York: Springer Science+Business Media, LLC, 2009.

4. S. De Haes and W. Van Grembergen, "IT Governance and Its Mechanisms," Proc. Annu. Hawaii Int. Conf. Syst. Sci., vol. I, no. Information Systems Control Journal, 2004.

5. J. W. Ross and P. Weill, "How Top Performers Manage IT Decisions Rights for Superior Results," IT Gov., 2004.

6. M. Leketi and M. Raborife, "IT Governance Frameworks and their Impact on Strategic Alignment in the South African Banking Industry," 2019 IST-Africa Week Conf., pp. 1-9, 2019.

7. I. S. Bianchi and R. D. Sousa, "IT Governance in Higher Education," in Procedia Computer Science, 2016.

8. B. Otto, "IT Governance and Organizational Transformation: Findings From an Action Research Study," 16th Am. Conf. Inf. Syst. 2010, AMCIS 2010, vol. 5, pp. 3749-3760, 2010.

9. PT. XYZ, “Annual Report 2013,” 2013.

10. PT. XYZ, "IT Strategic Plan 2014 - 2018,” 2018.

11. Boston Consulting Group, "Banks Brace for a New Wave of Digital Disruption," 2019.

12. PT. XYZ, “Annual Report 2018,” 2018.

13. L. M. Applegate, R. D. Austin, and D. L. Soule, Corporate Information Strategy and Management: Text and Cases, 8th ed. New York: The McGraw-Hill Companies, Inc., 2009.

14. S. Vejseli, D. Proba, A. Rossmann, and R. Jung, "The agile strategies in IT governance: Towards a framework of agile IT governance in the banking industry," 26th Eur. Conf. Inf. Syst. Beyond Digit. - Facet. Socio-Technical Chang. ECIS 2018, 2018.

\section{AUTHORS PROFILE}

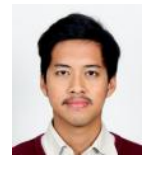

Aristides Fariz

Student in Faculty of Computer Science, University of Indonesia.

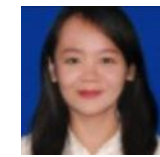

Theresia Nathania A. P.

Student in Faculty of Computer Science, University of Indonesia.

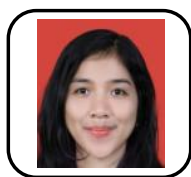

Ruth Magdalena

Student in Faculty of Computer Science, University of Indonesia.

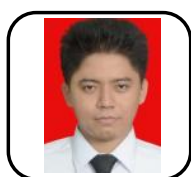

Muhamad Yasil F.

Student in Faculty of Computer Science, University of Indonesia.

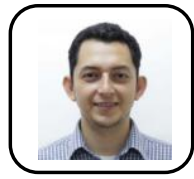

M. Rifki Shihab

Teaching staff in Faculty of Computer Science, University of Indonesia. 